\title{
有限要素法による地下鉄トンネル温熱環境シミュレーション \\ THERMAL SIMULATION OF SUBWAY TUNNEL BY FINITE ELEMENT METHOD
}

\author{
武田仁* \\ Hitoshi TAKEDA
}

\begin{abstract}
After thermal environments of a subway were surveyed for a year, the author developed a thermal environmental simulation program by the two- and three-dimensional finite element methods.

Affluent data obtained through the survey showed theoretical values were nearly coincident with actual figures.

The simulation found the outlet temperature of the tunnel rose 0.6 degree centigrade when ventilation facilities were stopped throughout the year, while it went up 1.0 degree centigrade when the heating value doubled.
\end{abstract}

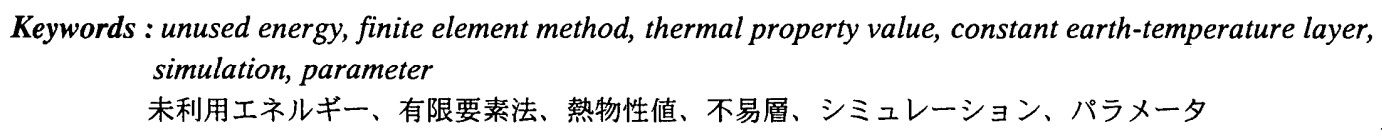

\section{1. はじめに}

最近、化石燃料の大量消費による地球温暖化、また、都市の排熱 によるヒートアイランド化が著しい。これら環境上の問題を解決す る手段として都市排熱などの未利用エネルギーの活用がクローズ アップされている。筆者は未利用エネルギーの一つである地下鉄排 熱に着目し、東京の代表的なビジネスセンターの地下鉄駅舎、トン ネルおよび換気塔における一年間(1992 年 1 月〜 12 月)の長期実測測 定結果を文献 1)に報告した。それらの結果を踏まえ、今後、地下鉄 の新設、あるいは既存の地下鉄で增加するであろう列車運行に伴う 発熱量の增加に対してトンネルの温熱環境を精度良く予測すること は重要なことである。これまでの地下鉄の実測またはシミュレー ションは水野らによる文献 2) 9)、文献 14)、15)、黒本、前川、高 木らによる文献 10)～13）、吉田らによる文献 16）、19）等が見られる。

今回筆者は熱伝導解析手法として有限要素法 (FEM) を適用し、熱物 性值を実測值より導き出し、実測值と理論值の検証を行い、換気量 および発熱量条件変化による長期間の地下鉄トンネル部の温熱環境 シミュレーションを試みた。

\section{2. 対累地下鉄の概要}

シミュレーションの対象として望ましい施設は、

(1)測定データがあり、検証可能なこと。

(2)施設が新しく、今後経年変化の測定が可能であること。 などがあげられる。筆者の調查施設は東京の地下鉄半蔵門線大手町 駅を挟む大手壕換気塔から常盤橋換気塔間 (約 $1 \mathrm{~km}$ )で行い、実測デー 夕は温度、湿度、風速などを 15 秒間隔で計測し、10 分間陾の平
均値データを採取している(計測点は文献 1 図 3 参照)。調査当時、 稼動して 4 年程度しか経過しておらず比較的新しい施設である。こ の路線の換気方式は機械換気による駅部給気、トンネル部排気で、 大手町駅舎で外気を取り入れ、駅構内、トンネル内を通過して、駅 舎之駅舎の中間部の大手壕換気塔と常盤橋換気塔から強制的に排気 している。駅舎、車西冷房期間は 4 月〜 11 月までの 8 ケ月間で、 営業時間は午前 $4: 30$ から翌日午前 $0: 30$ までである。これらを考慮 して、今回解析対象とした部分は、図 1 に示す渋谷方面行き(B 線) トンネルで大手町駅から大手壕換気塔までの区間(単線シールド、 476m)である。図 2 にトンネル断面図を示す。

\section{3. 解析方法}

トンネルの熱伝導解析法として、有限要素法 (FEM)による数値解析 を行う。有限要素法を用いる理由の一つに、差分法では原則として 直交格子点を採用せざるを得ないのに対し、トンネル内表面のよう な曲面にも三角形または四辺形などの任意形状を要素として精度良 く適用できることである。ここでは四辺形要素を適用し、2 次元モ デには高精度の解が得られる 8 節点アイソパラメトリック要素を 使用し、3 次元六面体モデルには 2 次元モデルを 3 次元に拡張した 20 節点アイソパラメトリック要素を使用した。

図 3 に示すように、トンネル断面に有限要素法を適用し、トンネ ルを $\mathrm{n}$ 個のセルに分割する。入り口空気温度 $T_{0}$ は最初のセル $C_{1}$ でト ンネル壁体表面の熱伝達、トンネル地中内の熱伝導により空気温度 $T_{1}$ が算出される。 $C_{1}$ の空気温度 $T_{1}$ は次のセル $C_{2}$ の入り口空気温度 として流入し、再び壁体表面の熱伝達、地中内の熱伝導が生じる。 
$1 \%=\operatorname{lm} \sqrt{1000 \mathrm{~m}}$

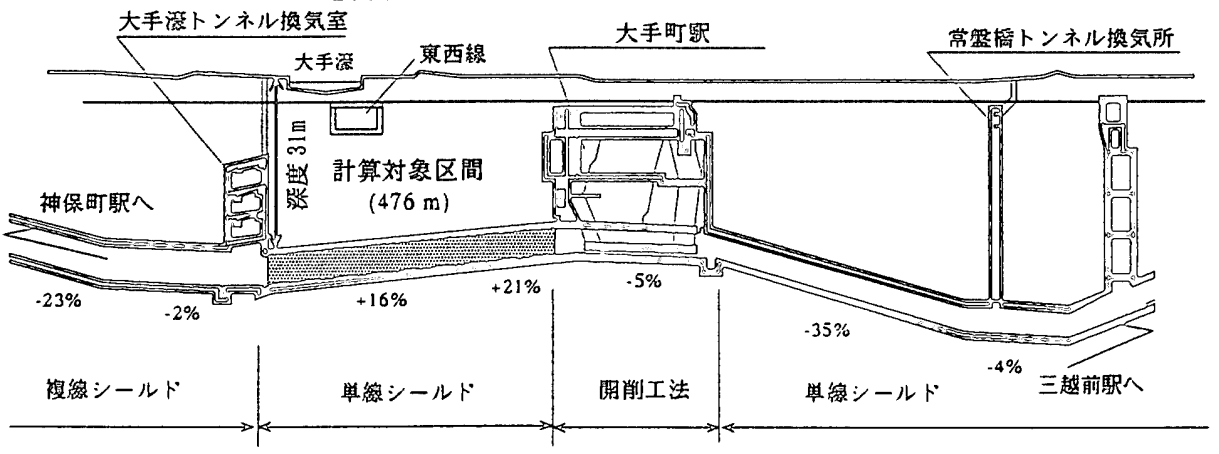

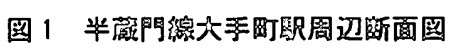
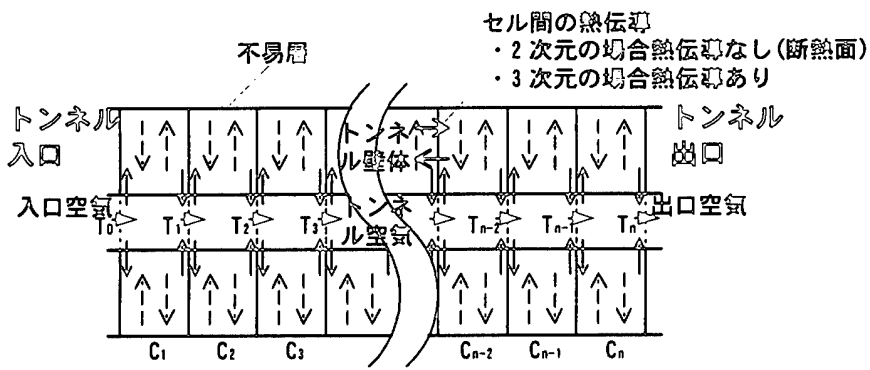

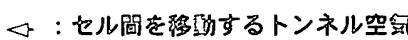

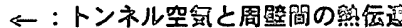

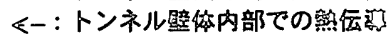

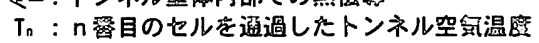

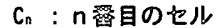

图 3 シミュレーション僇念圆

この過程を $\mathrm{n}$ 回䋓り返して、 $C_{n}$ における地中温度および空気温度 $T_{n}$ を求める。 $T_{n}$ がトンネル出口温度となる。このように、トンネル 空気の流れと直交するトンネルの地中温度分布とトンネル空気温度 を算出し、これを流れ方向に繰り返すことで、トンネルの非定常伝 熱を解析する。なお、実測調查結果文茄 1)よりトンネル壁体表面にお ける吸放湿は無視できるほど小さいことが判明しているので、ここ では顕熱挙動のみを取り扱う。

トンネル壁体表面の熱流は、各セルの壁体表面温度は均一とみな

し、壁面は対流熱伝達が支配するものとする。

セル番号 $i$ のトンネルの熱収支式より、次の式が得られる。

$$
T(i)=T(i-1)-\frac{Q(i)}{C_{V} \cdot V \cdot S}+\frac{H}{C_{V} \cdot V \cdot S \cdot N} \quad \text { 式(1) }
$$

$i:$ 空気の流れに治ったセル番号

$T(i): i$ 番目セルの空気温度変化 $[\mathrm{K}]$

$Q(i): i$ 番目セルのトンネル壁面への流出熱量 [W]

$H$ : トンネル内全発熱量 [W]

$N$ : トンネル分割数, $A$ : 1 セルのトンネル壁面積 [m

$C_{V}:$ 空気の容積比熱 $\left[\mathrm{kJ} / \mathrm{m}^{3} \mathrm{~K}\right], V$ : トンネル内風速 $[\mathrm{m} / \mathrm{s}]$

$S$ : トンネル断面積 $\left[\mathrm{m}^{2}\right]$

トンネル壁面への流出熱量 $(Q(i))$ は、

$$
Q(i)=\alpha_{C V} \sum_{j} A_{j}\left(T^{\prime}(i)-T^{\prime}{ }_{S}(i)_{j}\right)
$$

である。

$T^{\prime}(i)$ ： $\Delta t$ 時間前の空気温度 $[\mathrm{K}]$

$T^{\prime}{ }_{S}(i)_{j}: \Delta t$ 時間前のトンネル壁面節点 $j$ の温度 [K]

$A_{j}:$ 節点 $j$ のトンネル壁要素面積 $\left[\mathrm{m}^{2}\right]\left(A=\sum_{j} A_{j}\right)$

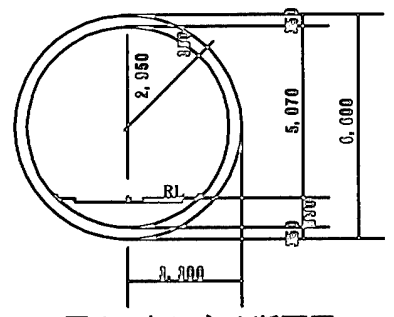

图 2 トンネル断面图 トンネル (入口) 空氧》 [蚠測傊]

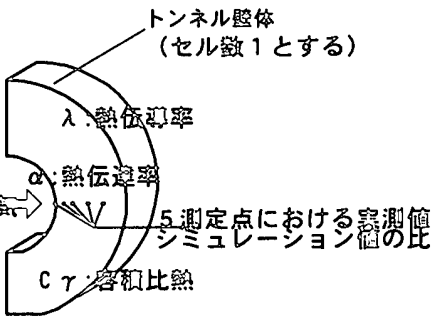

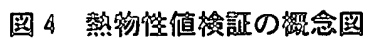

\begin{tabular}{|c|c|c|c|}
\hline タイプ & 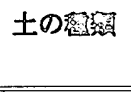 & 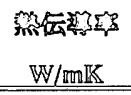 & 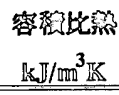 \\
\hline $\mathbb{1}$ & ローム & 1.050 & 1033.1 \\
\hline 2 & 火山灰 & 0.721 & 974.5 \\
\hline 3 & 粘土質(1) & 1.850 & 1504.9 \\
\hline 4 & 粘土質(2) & 0.651 & 896.6 \\
\hline 5 & 粘土質(3) & 1.850 & 896.6 \\
\hline
\end{tabular}

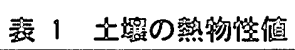

文献 21) 参照

なお、列車往来により壁面近傍の風速は激しく変化することが文 献 1 で判明しており、ここではそれらを含んだ平均風速をユルゲス の実験式に適用し、対流熱伝達率を算出する。

$$
\alpha_{c v}=1.163(5.3+3.6 v) \quad \text { (粗面) }(v \leq 5 \mathrm{~m})
$$

$\alpha_{c v}$ : 強制対流熱伝達率 [W/ $\left./ \mathrm{m}^{2} \cdot \mathrm{K}\right], 1.163$ : 換算係数, $v$ : 平均風速 $[\mathrm{m} / \mathrm{s}]$

実測值との比較の場合、換気塔ファン運転時のトンネル内風速 $(V)$ は終電通過後、トンネル内に入り JIS B 8615 の円形管路の測定 点に準拠して熱線風速計で測定した平均風速 $1.68 \mathrm{~m} / \mathrm{s}$ (一定值)を用 いた。また、対流熱伝達率に適用する風速は列車往来の影響を受け るトンネル壁面近傍で連続測定した風速の平均値を用いた。なお、 具体的数值シミュレーションは東京理科大学情報処理センターの ワークステーションを利用した。

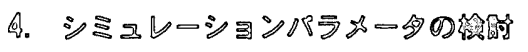

シミュレーションプログラムの精度の検討を行う場合、各々のパ ラメータは相互に関係しあうので、1 つのパラメータのみを取り出し て決定するのは困難な場合があるが、全体のシミュレーションへの 影響を考虑しながら決定したパラメータをフィードバックして逐次 決定した。

(1)熱物性値

トンネル壁面はコンクリートのシールド厚 $350 \mathrm{~mm}$ であり、その周 囲はすべて土壌で覆われている。トンネルの解析を行う場合、蓄熱 


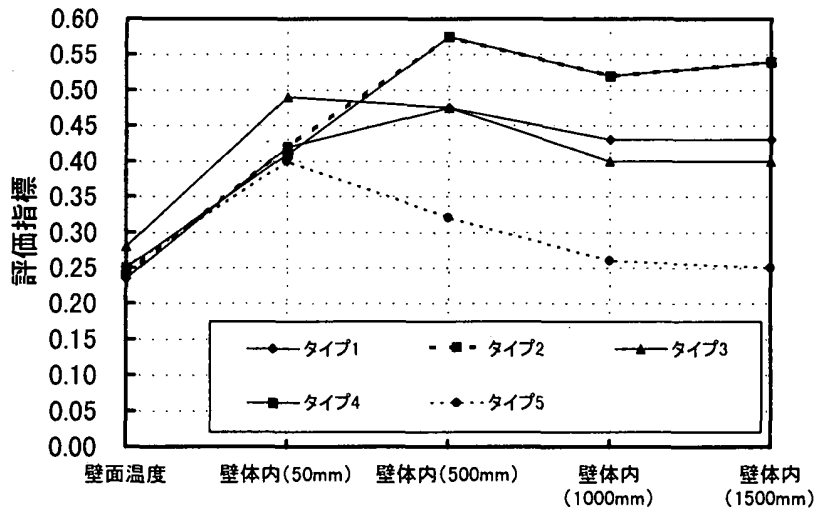

図 5 熱物性値評価指標 (年平均値)

が大きな問題となり、それに関係する周囲の土壤の熱物性値 (熱伝導 率、容積比熱) は大切である。実測調査でトンネルをボーリングし熱 電対を埋設した際の土嚊の感触では、比較的含水率の高いものと思 われた。そこで、可能性のありそうな熱伝導率、容積比熱の組み合 わせ 5 タイプを表 1 のごとく想定した。1 月から 12 月までの 1 年分 の実測データを図 4 のように測定空気温度、計算時間間隔ともに 10 分として入力し計算を行った。壁面〜壁体内 $(1500 \mathrm{~mm})$ の 5 点の理論 計算温度と実測値の比較の評価指標として、

理論值と実測值の評価指標

$$
=\frac{\text { 各深さにおける理論値一各深さにおける実測値 }}{\text { 計算回数 }}
$$

を定義した。その結果を図 5 に示す。評価指標の最も良かったタイ プ 5 の熱物性值を採用することとした。

(2)トンネル断面のメッシュ

トンネルは図 2 に示すごとく単線シールドで左右対称とみなせる。 トンネル断面の半分の形状を四辺形要素を適用して不易層に至るま で、図 6 に示す要素数 135 、節点数 470 とした。トンネル空気と接す る面近傍は可能な限り微細に要素数を分割し、温度変動の少ない不 易層に近づくに従い、粗いメッシュとし、地表面の熱授受は考慮に 入れなかった。まず、熱挙動を把握するため不易層までの距離を $70 \mathrm{~m}$ とし、2 年間の予備計算(実測デー夕 1 年分を繰り返し使用)を行った 後の 3 年目の計算結果を検討した。なお、不易層の温度は文献 1)の 調查を参考に $22.1{ }^{\circ} \mathrm{C}$ とした。図 7 に奇数月の月末の断面温度分布を 示す。これを見ると 1 年周期では大きな温度変動は表面から $10 \mathrm{~m}$ 以 内で、20m のところではほとんど変動がない。不易層は $20 \mathrm{~m}$ 程度と思 われる。今回のシミュレーションでは、不易層までの距離を念のた め30m とした。

(3)計算時間間隔

一般に計算時間間隔を短くすれば、精度が上がるが、計算に要す る時間は增す。目的に応じて時間間隔を検討する必要がある。実測 測定間隔は 10 分であるが、計算時間間隔を 10 分および 1 時間を検 討した。計算条件は、先に述べた条件を用い、トンネル長さ方向の 分割は 10 分割とした。1 年間の予備計算をおこなった後の 2 年目の 代表的な 9 月の断面温度分布を図 8 に示す。トンネル空気の温度変 化が激しい時期で差が大きくなっているが、最大でも $0.15{ }^{\circ} \mathrm{C}$ 以下で あり、長期計算の場合は計算時間間隔が 1 時間でも問題はないと言 える。今回のシミュレーションでは 10 分間隔とした。

(4) トンネル方向の分割数

トンネル内の空気の流れの方向の分割数は、計算時間間隔と同様

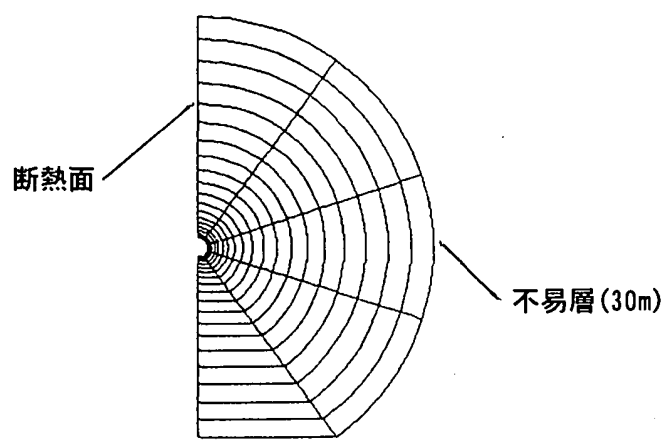

图 6 トンネル断面のメッシュ

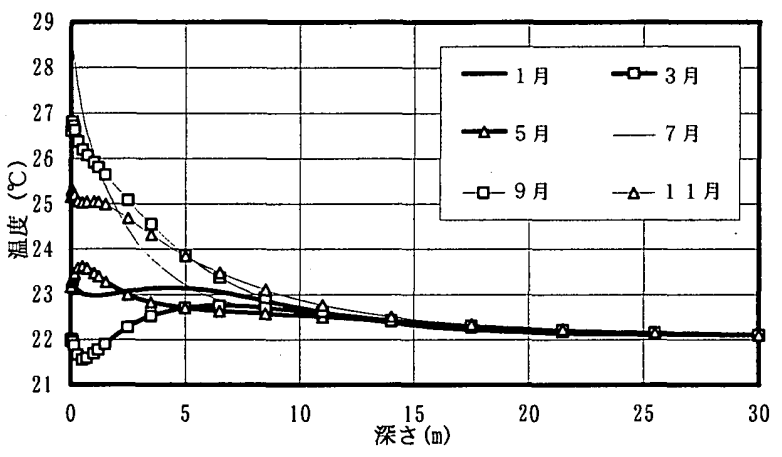

图 7 奇数月の月末のトンネル断面温度分布

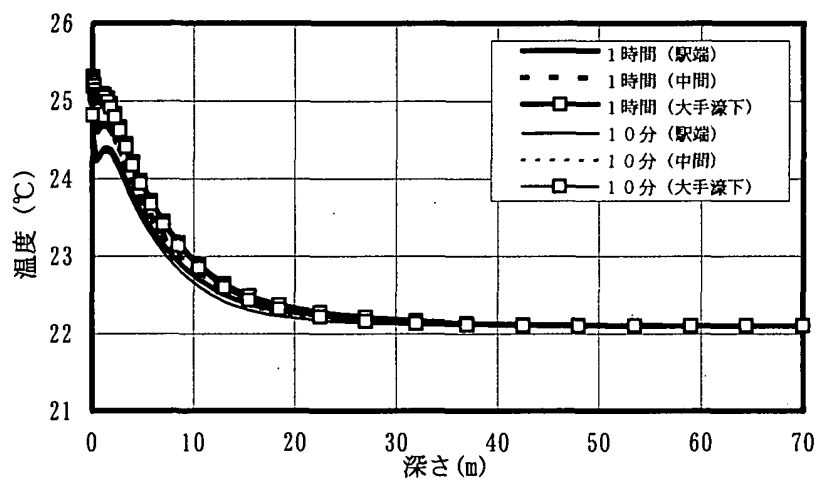

図 89 月末の断面温度分布(時間間隔 10 分と1 時間)

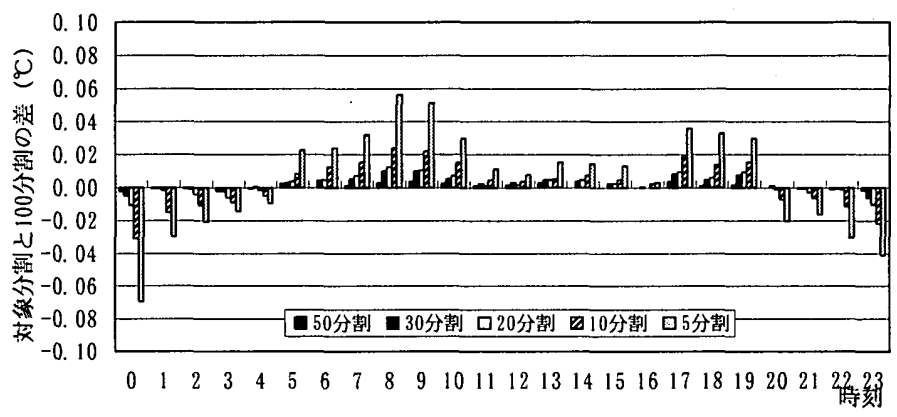

図 9 分割数の違いによるトンネル出口空気温度

に分割数と目的の精度を考慮しなければならない。ここでは、100 分割を基準にして $5,10,20,30,50$ 分割を検討した。評価指標として 温度誤差評価指標

=対象とする分割数の温度-100 分割の温度

を定義し、各時刻における差の平均值を図 9 に示す。これによると 差の大きさが、評価指標で $0.04^{\circ} \mathrm{C}$ 以上になるのは、5 分割のときの 
みで、長期計算では 10 分割で十分と思われ、この分割数を採用した。 （5）トンネル内発熱量の推定

トンネルの入りロ空気温度 (プラットホーム端空気温度)には駅舎 およびプラットホーム発熱量が含まれていると考えられ、ここでは トンネル部のみの発熱量を算出する。発熱量の算出根拋は全て営団 地下鉄所有の資料に基づいた（注 1)。発熱量は列車走行に伴う発生熱、 車両冷房機発生熱および人体発生熱である。冷房は全車両の冷房で あり、車両冷房期間は $4 / 15 \sim 11 / 15$ 、車内設定温度は $26^{\circ} \mathrm{C}$ である。 プラットホーム部の気温を考虑して、非冷房期 (12 3 月)、冷房期

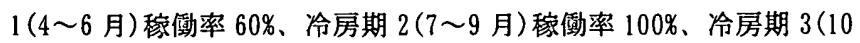
〜11月)稼僖率 $50 \%$ 分けた。各時刻における列車運行本数は、平日、 休日の列車㖶行ダイヤ、乗車人員は乗車人員調疽資料に基づいた。 上記の諸条件をもとに発熱量を算出した。その結果を図 $10 、 11$ に示 す。なお、この推定発熱量は、実測とシミュレーションとの比較検 討が必要である。

このように(1) は実測値との検証、（2）〜（4）は数值計算上の精度 の検定、（5）は事業者の資料に基づいて検討を行った。

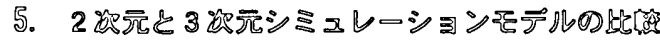

ここまで述へてきた計算結果は 2 次元 FEM モテルのアルゴリズム を利用した。しかし、現実のトンネルは幾何学的に 3 次元構造であ るので、熱的に 2 次元、3 次元の比較検討が必要である。図 3 のご とく、2 次元モデルではトンネルの長さ方向のセル間は断熱境界で あるが、3次元モデルではセル間で熱流が生じることになる。3次 元モデルは図 12 のごとく断熱面の影響を少なくするためトンネルの 両端面に最端部断熱の 1 分割面 (1 セル分) 各々 $47.6 \mathrm{~m}$ 追加し、トンネ ル長さを $571.2 m$ とした。その結果、要素数 1620 、節点数 8126 と大 メモリーが必要となった。1例として、図 13 に 7 月 31 日 24 時の 2 次元と 3 次元の出口檵面地中温度分布の計算結果の比較を示す。 2 次元と 3 次元の温度が 1 年を通じて差が大きな時間帯である。地中 温度は表面近傍で 2 次元の方が高く、1.5m 以上の深さでは、逆に 3 次元の方が高くなる。これは 3 次元では土㙥の軸方向に熱流が生じ、 温度が均一化されたためと思われる。しかし、重要な出口空気温度 は $0.06^{\circ} \mathrm{C}$ 差程度である。同じ程度の結果を得るため、2 次元モテル から 3 次元モデルに移行すると入カデータが複雑になり計算時間も 非常に長くなる。

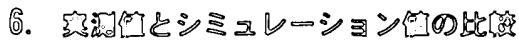

実測值とシミュレーション結果の比較検討を行った。なお、トン ネル内発熱量は 4.（5)のトンネル内発熱量の推定を用い、推定值が 妥当か否かの検討も行った。

(1) 2 次元、3 次元モテルと実測値の比較

実測值のデータ取り込み間隔 10 分に合わせ、計算時間間隔を 10 分とした。赛測値および 2 次元、3 次元シミュレーション結果の比較 検討を行ない、その結果を図 14 に示す。

1) 出口空気温度

2 次元. 3 次元とも挙動は実測值と良く合致している。トンネル内 空気温度の算出は正確に行っていると思われる。詳細に見ると 2 次 元の方が 3 次元に比べ営業時間で $0.3 \sim 0.4{ }^{\circ} \mathrm{C}$ 高く、非営業時間では ほぼ同じ値になっている。営業時間帯の実測值との比較では 3 次元

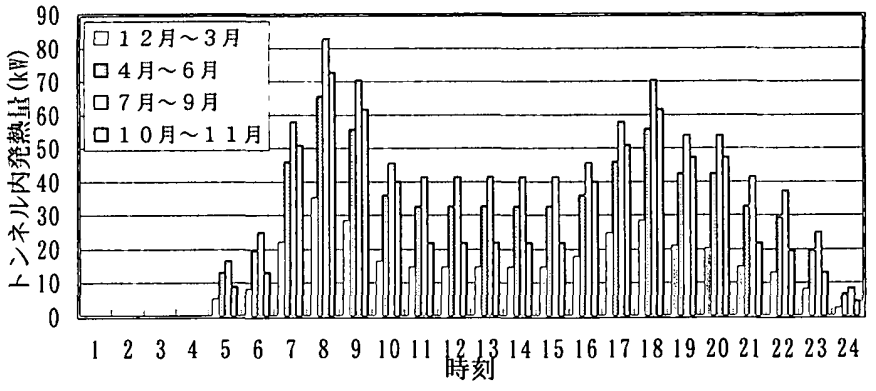

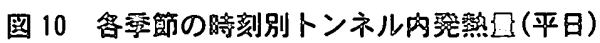

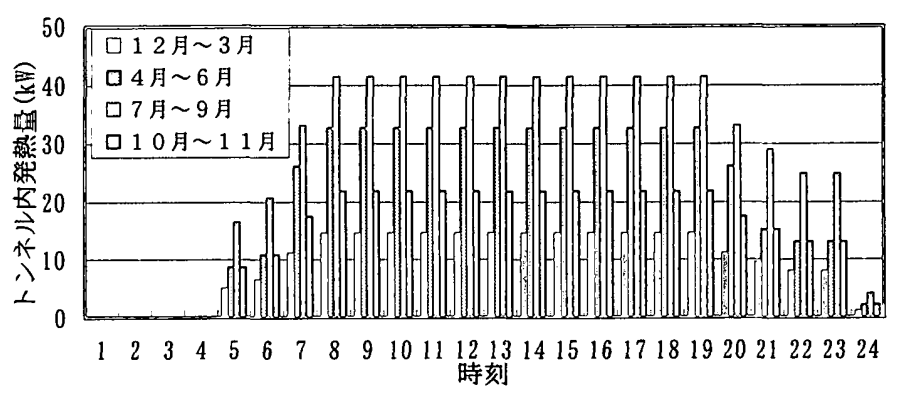

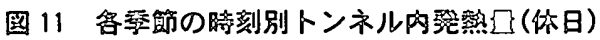

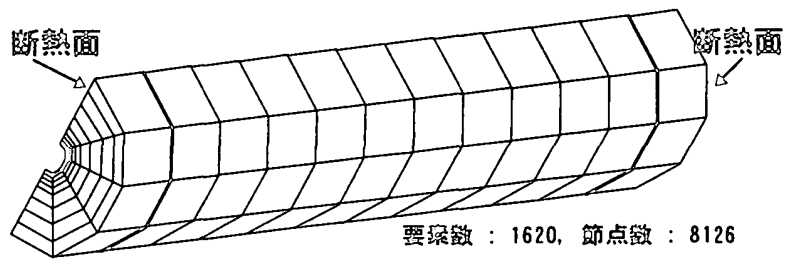

图 123 次元のメッシュ

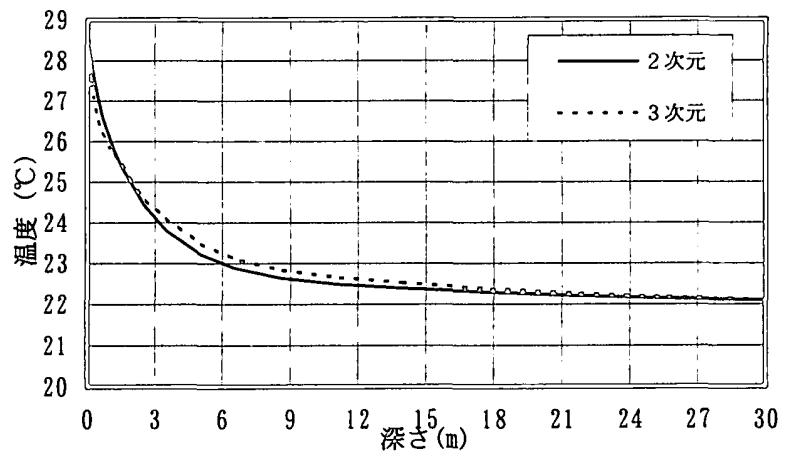

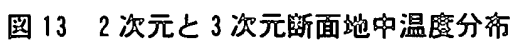

は約 $0.5^{\circ}$ C程度低い值を取っているのに対し、2 次元の方が実測値に 非常に近い值となっている。非営業時間帯においては実測值に対し、 2 次元、 3 次元とも $0.7^{\circ} \mathrm{C}$ 程度低い。これはシミュレーションモテル が強制対流を対象とした壁面近傍平均風速に基づき熱伝達率を計算 しているのに対し、実態は列車が運行していない時壁面では自然対 流が支配的になるためと考えられる。

2)トンネル表面温度

2 次元、 3 次元とも温度挙動は実測値とよく合っている。営業時間 帯においては、2 次元の方は $0.2^{\circ} \mathrm{C}$ 程度実測值より低いが、発熱量が 多い平日ではほとんど誤差がない。3 次元の方は実測值に比べ約 $1^{\circ} \mathrm{C}$ 低くなった。表面温度に関しては、2次元モデルの方が実測値と良く 合う結果となった。 

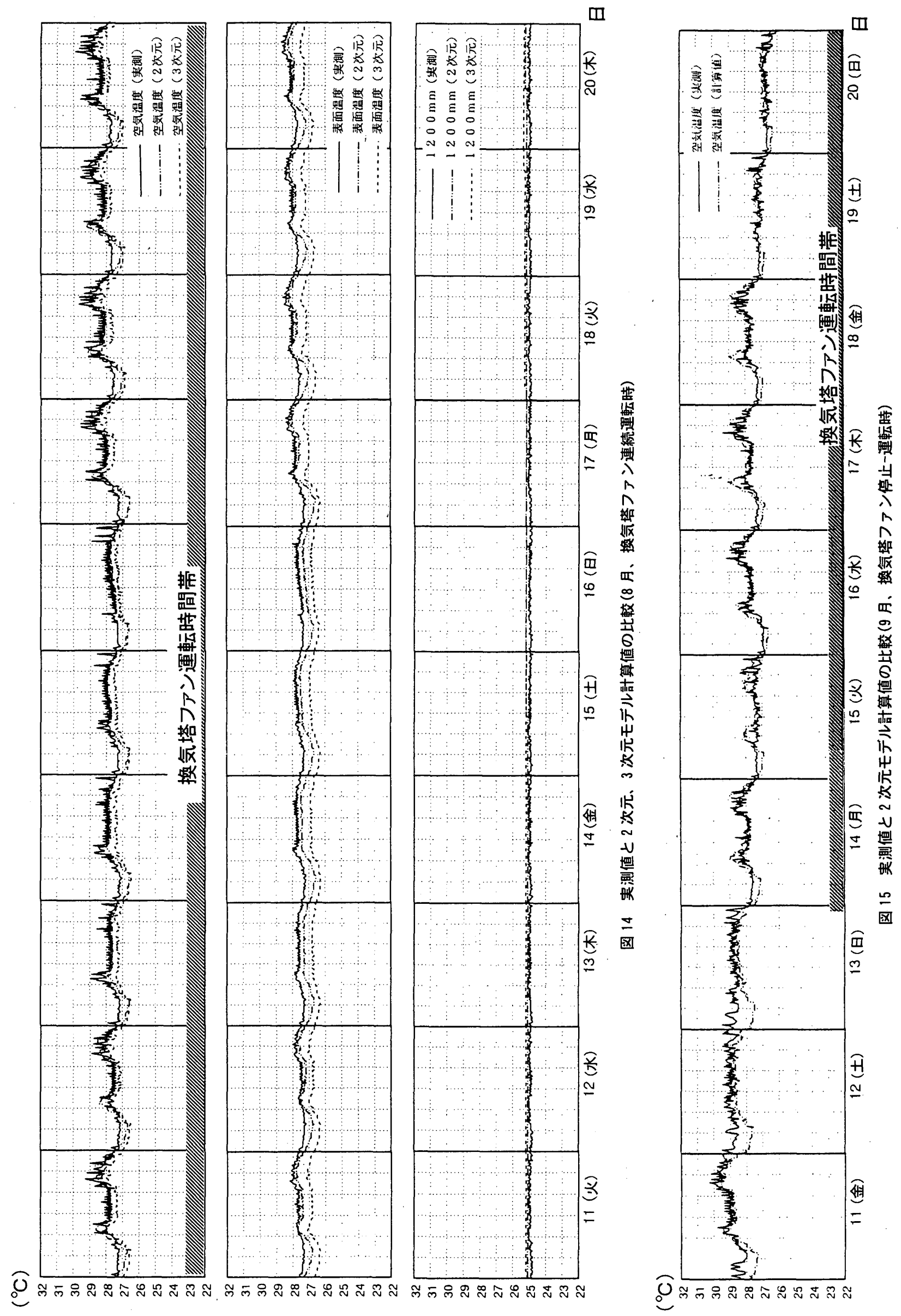


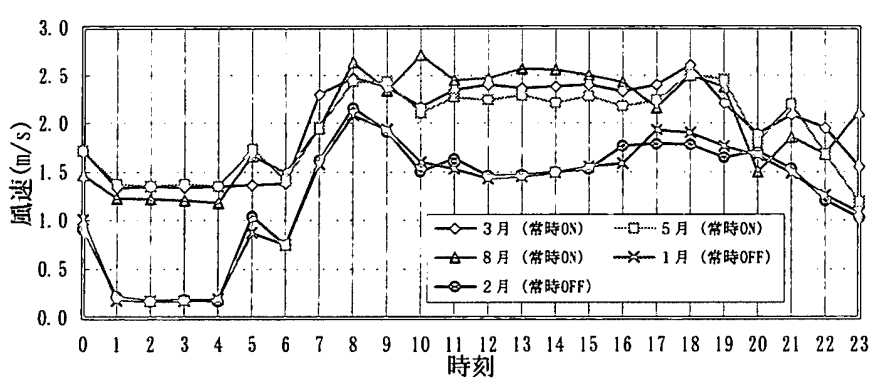

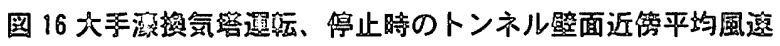
（測定点は立献 1 图 3 贸照)

\section{裴2 告タイプの設定等件}

\begin{tabular}{|c|c|c|c|}
\hline $917^{\circ}$ & トンネル内同虺 & 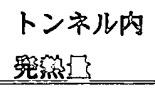 & ホーム然の经件 \\
\hline 1 & $\begin{array}{l}\text { 標準 (換気塔薑転時 } 1.68 \mathrm{~m} / \mathrm{s}, \\
\text { 換気塔停止時 壁面近傍平均風速 ) }\end{array}$ & $\begin{array}{l}\text { 標準 } \\
\text { (図 10,11) }\end{array}$ & 実測値 \\
\hline 2 & 換気塔摆転時の風速 $(1.68 \mathrm{~m} / \mathrm{s})$ & 標準 & 実測值 \\
\hline 3 & 換気塔停止時の風速（壁面近傍風速） & 標淮 & 実測値 \\
\hline 4 & 標準 & 標準 $\times 1.1$ & 実測値 \\
\hline 5 & 標準 & 標準 $\times 2.0$ & 実測值 \\
\hline 6 & 標準 & 標準 & $\begin{array}{l}\text { 実測値 }+1.6^{\circ} \mathrm{C} \\
\text { (ラッシュ時 } \\
\text { 上昇温度 } \times 2.0 \text { ) }\end{array}$ \\
\hline
\end{tabular}

3) 地中温度

トンネル表面から $50 \mathrm{~mm}$ の媣さにおいて、非営業時間において実測 值とやや温度差が大きくなる傾向があるが、営業時間では 2 次元の 方がよくあっており、3 次元の方は $0.3{ }^{\circ} \mathrm{C}$ 程度低くなる。ただ、発熱 量の多い平日においては、2 次元は実測值より温度が高く、3 次元は 実測值に近づく傾向があり、実測值が 2 次元と 3 次元の間になる。 $500 \mathrm{~mm}$ の樑さでは、1 日のトンネル空気温度変化に対して大きな変化 が見られなくなる。2 次元の方がやや高く 3 次元の方がやや低く実測 値を挟み込む形となっている。1000m の深さにおいては、2 次元と 3 次元の計算結果はほぼ同じである。実測值と比較すると計算值が約 $0.2^{\circ} \mathrm{C}$ 程度高くなっている。1200mm の深さでは実測值と計算値がよく 合うが、 3 次元の方がやや温度が高くなる傾向がある。

結論として、3 次元モデルは 2 次元モデルに比ベ、インプットデー 夕の作成、計算時間等费やす労力に比べ、精度などの成果がそれほ どあがらないことが判明した。物性值を 2 次元モデルに合うように 決定したせいもあり、実測値との比較ではむしろ 2 次元モデルの方 がよく合う場合もある。シミュレーションでは 2 次元モテルル゙十分 と思われる。また、トンネル内発熱量の推定值も、シミュレーショ ンに利用できることが判明した。

(2) 換気塔ファン停止時の 2 次元モテルと実測值との比較 実測值とシミュレーション結果の換気塔ファン停止時の出口空気 温度比較を図 15 に示す。

一時換気塔を停止した場合、実測空気温度が上昇し、シミュレー ションでは追従できない。換気塔の運転を開始すると、実測值と計 算值は比較的一致する。換気塔停止時のシミュレーションは囷難で あるが、風速が微風速なので、熱量的な誤差は小さいと思われる。

全体的に換気塔を運転しているときの空気温度、表面温度などの シミュレーション結果の精度は高い。換気塔を停止している非営業

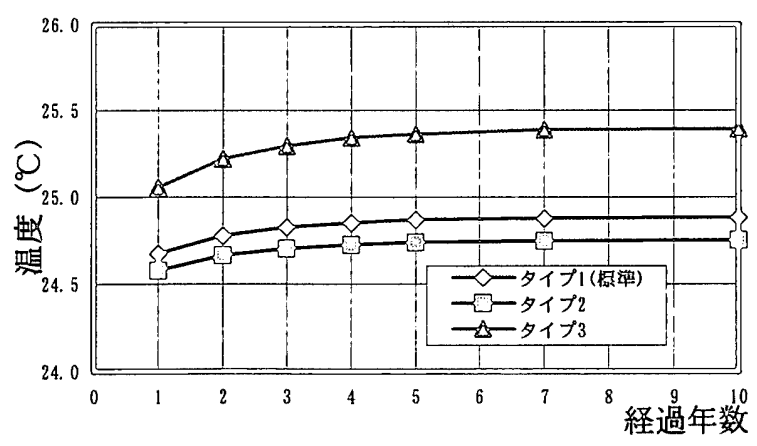

图 17 谄氞口の逼いによる年平均出口空氞温噔

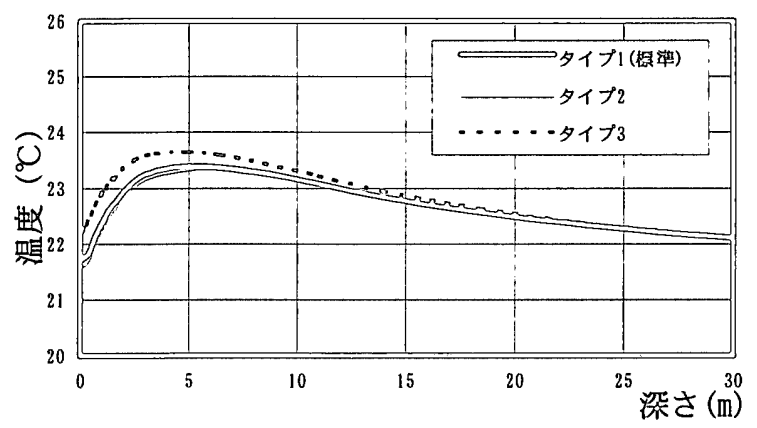

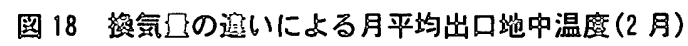

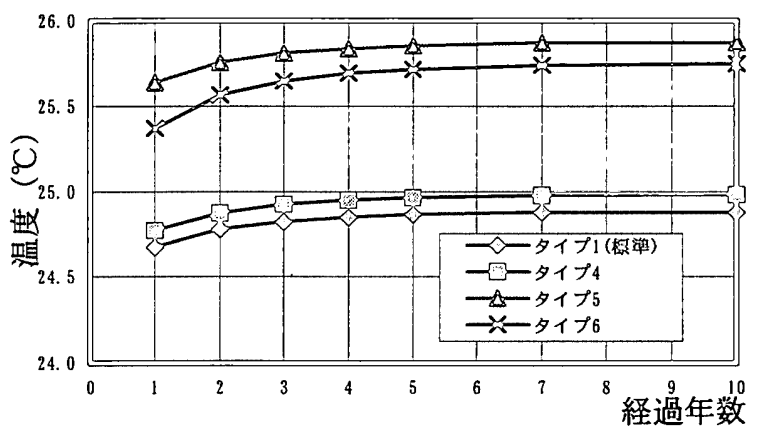

图 19 玩熱口の迎いによる年平均出口空氞温噔

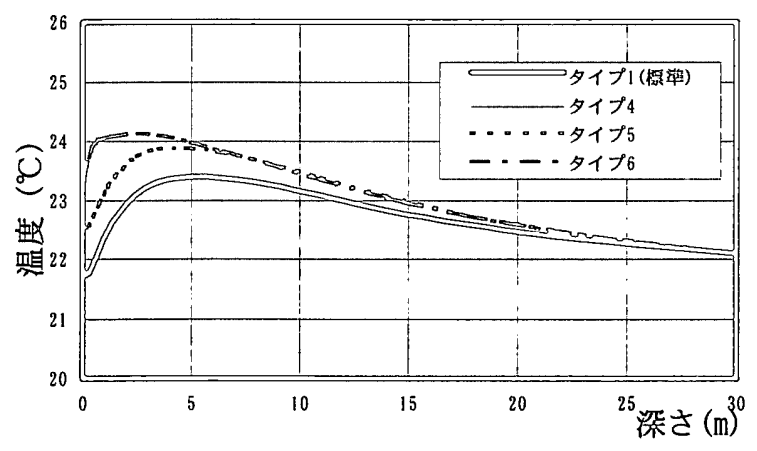

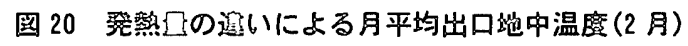

時にやや誤差を生じるものの、このモデルを長期シミュレーション モデルとして問題ないと言える。

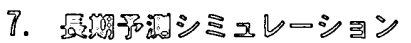

換気量および発熱条件を表 2 に示す 6 タイプを設定し、各タイプ とも 10 年間のシミュレーションを行った。トンネル壁面近傍の平均 風速を図 16 に示す。この実測風速を基に対流熱伝達率を算出した。 


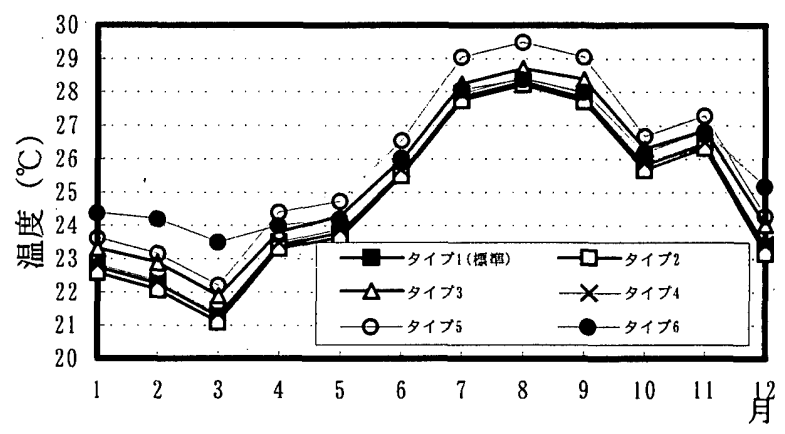

图 21 各設定による月平均出口空気温度

（1）換気量が变化した場合

タイプ1--- - 標準。対流熱伝達率は、実測期間中の運転時および停 止時の平均風速に基づく。

タイプ 2--- - 常時運転。対流熱伝達率は、終日換気塔が稼動してい る日の平均風速に基づく。

タイプ 3--- - 運転停止。対流熱伝達率は、終日換気塔が停止してい る日の平均風速に基づく。

シミュレーション結果を図 $17 、 18$ に示す。出口空気温度に関して はタイプ1(標準)に比ベ、タイプ 2 は、 $0.11^{\circ} \mathrm{C}$ 下がる程度である。夕 イプ1に比べ、タイプ 3 は $0.5^{\circ} \mathrm{C}$ 程度上昇する。換気の必要性が認め られる。出口地中温度分布は、トンネル表面では夕イプ 2 は夕イプ 1 に比べ $0.1^{\circ} \mathrm{C}$ 低く、タイプ 3 は $0.5^{\circ} \mathrm{C}$ 高い。この差は土中深くなるに 従い小さくなる。

（2）トンネル内発熱量が増加した場合

トンネル内発熱量を 2 種類想定した。

タイプ 4-----現在の発熱量の若干増加 (現在の発熱量を各時刻 1.1 倍する。トンネル内風速、対流熱伝達率はタイプ 1 と同様とする。） タイプ 5-----現在の発熱量の極端增加（現在の発熱量を各時刻 2.0 倍する。トンネル内風速、対流熱伝達率は夕イプ 1 と同様とする。） シミュレーション結果を図 19、20 に示す。出口空気温度は、タイ プ 1 に比ベタイプ 4 は $0.1^{\circ} \mathrm{C}$ 高く、タイプ 5 は $1.0^{\circ} \mathrm{C}$ 程度極端に高く なる。出口地中温度分布はタイプ 1 と比較して、タイプ 4 はほとん ど変わりなく、タイプ 5 は表面付近で約 $1.0^{\circ} \mathrm{C}$ 高い。梁くなるに従い、 その差は小さくなる。

（3）トンネル入口空気温度が上昇した場合

トンネル入口空気温度を 1 種類想定した。

タイプ 6----入口空気温度上昇 (平日の AM7:00 10:00、PM5:00 9:00 にトンネル入口温度をラッシュ時に上昇する温度の 2 倍を想定 し実測值 $+1.6^{\circ} \mathrm{C}$ とする。トンネル内風速、対流熱伝達率は夕イプ 1 と同様とする。)

タイプ 6 の想定した $1.6^{\circ} \mathrm{C}$ 上昇を熱量換算すると約 $81 \mathrm{~kW}$ で、トン ネル内発熱量の平日ピークの 8 時と同等となり、その発熱量を上乗 せしていることになり、トンネル温度に与える影響は大きく出た。 計算結果を図 $19 、 20$ に示す。年平均出口空気温度はタイプ 5 近くま で上昇する。出口地中温度は、タイプ 1 に比べ表面付近で $2{ }^{\circ} \mathrm{C}$ 近く高 くなるが、徐々に差が小さくなり、7m以上の深さでは、タイプ 5 と 同様の温度分布になる。

まとめとして各月平均出口空気温度の比較を図 21 に示す。タイプ 5 は夕イプ 1 と比べると 1 年を通して平均 $1{ }^{\circ} \mathrm{C}$ 高くなる。タイプ $2 、 3 、$
4 についてはタイプ1 と同じょうな変動をする。タイプ 6 は発熱量の 多い時期 $(7 、 8 、 9$ 月)は夕イプ1 と変わらないが、非冷房期では空気 温度を相当上昇させる。

\section{8. 蛙睮}

結論として以下の事が言える。

(1)地下鉄トンネルの非定常解析に有限要素法を用いた。今回採用し た 2 次元四辺形 8 節点および 3 次元六面体 20 節点アイソパラメト リック要素は辺の中間にある節点を通る二次曲線で近似するので トンネルのように曲線を含む問題には最適である。

(2) トンネル断面の有限要素数は 135 、計算時間間隔 10 分、トンネル 方向分割数 10 分割で十分計算精度が碓保できる。

(3)実測地点のトンネル周囲の土壤の熱物性值は熱伝導率 $1.85 \mathrm{~W} / \mathrm{mK}$ 、 容積比熱 $897 \mathrm{~kJ} / \mathrm{m}^{3} \mathrm{~K}$ 程度と思われる。

(4) 2 次元と 3 次元モデルの比較を行った。空気温度は最大で $0.1^{\circ} \mathrm{C}$ 差 が生じる程度であった。地中温度に関しては、表面付近で 2 次元 の方がやや高く、深いところで 3 次元の方がやや高くなった。今 回のシミュレーションは、出口空気温度を重点的に取り扱ってい るので、2 次元モデルで十分精度が出ることが確認できた。今後 の課題として、3 次元モデルの計算時間の短縮である。計算機能 力向上は言うまでもないが、今回高精度の 20 節点アイソパラメト リック要素を用いたが、精度にあわせた要素の使い分けのエ夫が 必要であろう。

(5)シミュレーションモデルによる空気温度およびトンネル表面付近 の地中温度の計算結果は実測値とよく一致した。地中温度では、 計算結果の方がやや高くなり $500 \mathrm{~mm}$ で $0.5^{\circ} \mathrm{C} 、 1000 \mathrm{~mm}$ では $1{ }^{\circ} \mathrm{C}$ 近 く差が生じた。空気温度に関しては強制対流を前提として解析を 行ったため換気塔が停止している非営業時間に差が生じた。

(6)長期シミュレーションより現状に比べ以下の結果を得た。

- 換気塔が 1 年中停止すると、年平均出口空気温度は $0.6^{\circ} \mathrm{C}$ 程度上 昇する。

・トンネル内発熱量が 1 年を通して 2 倍になると、年平均出口空気 温度は $1.0^{\circ} \mathrm{C}$ 程度上昇する。

・ラッシュ時のみプラットホーム部(入口) 空気温度が上昇し、他の 時間帯は現状維持とすると、出口温度は非冷房期には上昇するが、 夏期には現状と比較してほとんど変わらない。

\section{9. おわりに}

1 年間の実測結果を踏まえ, 有限要素法を用いたシミュレーション プログラムを作成、検証を行った。また、そのプログラムを用いて、 精度の高い予測シミュレーションも行った。今後はさらにいくつか のパラメータを設定することにより、多くの事象を想定したシミュ レーションが可能になると思われる。

\section{既辞}

地下鉄実測を計画立案した丸の内熱供給(株)、実測を許可した帝 都高速度交通営団の各位に感謝致します。さらに、有限要素法に関 して東京理科大学菊池正紀教授にご指導を睗った。またコンピュー タシミュレーションの計算では村田知毅君、柳澤克宏君 (当時東京理 科大学大学院生)にご無理をかけました。記して謝意を表します。 
注 1 列車走行発生熱及び哈房機発生熱の推定（営団地下鉄所有資料） 車両条件は 1 編成 10 両、大手町駅と換気塔間の滞在時間は 59 秒と した。

(1) 列車走行発生熱

a) 制動発生熱計算式

$q_{A}=1.163 \times\left\{\frac{W+w \cdot \eta_{T}}{427} \times \frac{V_{A}^{2}}{2 \cdot g}+\frac{W}{427} \times \Delta H\right\} \times(1-\alpha) \times N$

$q_{A}:$ 制動区間での発生熱 [田]

$W:$ 列車重量 $(1$ 編成当たり $)=w+n \times 55 \mathrm{~kg} /$ 人 $[\mathrm{kg}]$

$w:$ 車両自重 $(1$ 編成当たり) $=285400[\mathrm{~kg}]$

$V_{A}$ : 最終制動地点での列車速度 $=9.7[\mathrm{~m} / \mathrm{s}]$ （運転曲線による）

$n$ : 乗車人員 ( 1 䋹成当たり) [人] (乗車人員調㚗資料による)

$g:$ 重力加速度 $=9.8\left[\mathrm{~m} / \mathrm{s}^{2}\right], \Delta H:$ 標高差 $=H_{A}-H_{S}=0.65[\mathrm{~m}]$

$H_{A}$ : 最終制動地点での標高 [m], $H_{S}$ : 停車点の標高 [m]

$\alpha$ : 実回生電力比 jッ江時 (0.4), 閶散時 (0.3)

$N$ : 到着列車本数 [本/ $\mathrm{h}$ ] (列車運行ダイヤによる)

$\eta_{T}:$ 回転潰性係数 $=0.08$

b) 加速発生熱計算式

$$
q_{B}=q_{A} \times 0.25, \quad q_{B}: \text { 加速発熱量 [ }[\text { ] }
$$

c) 補機発生熱計算式

$$
q_{C}=\left(q_{A}+q_{B}\right) \times 0.05, \quad q_{C}: \text { 補機発熱量 }[\mathrm{W}]
$$

（2）車両冷房機発生熱(1 編成あたり)

$$
q_{D}=M \times \beta
$$

$q_{D}$ : 冷房機発生熱 [田]， $M$ : 冷房機モ一夕入力 $=200000$ [W],

$\beta$ : 稼僖率 [-]

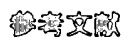

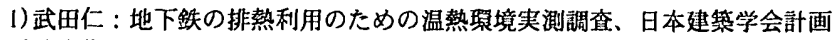
系詥文集 No. 474、PP. 7 15、1995.8

2) 水野稳、下田吉之、花井裕、内藤和夫 : 地下鉄を例とした地下空間の熱環 境シミュレーション(1) 一換気量、ホーム部気温の実測一、日本建筑学会学 術謨演梗楖集 PP. 221 222、1988.10

3）下田吉之、花井裕、皮野稳、内藤和夫 : 地下鉄を例とした地下空間の熱珢 境シミュレーション(2) ーシミュレーション結果と实测結果の比皎一、日本 建築学会学術講演梗概集 PP. 223 224、1988.10

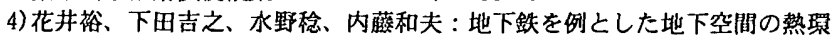
境シミュレーション(3) ーパラメータ・スタティー、日本建筧学会学術满演 梗摡集 PP. 225 226、1988.10

5) 田中亚二、花井裕、下田吉之、水野稳、内藤和夫 : 地下鉄を例とした地下

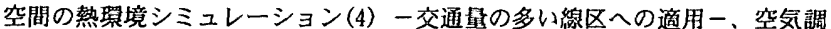
和・衙生工学会近畿支部学術研究発表会請演諭文集 PP. 15I 154、1989. 3 6) 花井裕、下田吉之、水野稳: 地下鉄を例とした地下空間の熱䇾境シミュレー ション(5) 一列車風の予測と実測結果の比皎一、日本建筑学会近聝支部研究 報告集 PP. 133 136、1989.3

7)花井裕、下田吉之、水野稳: 地下鉄を例とした地下空闑の熱琼境シミュレー ション(6) 一列車風の予測と実測結果の比較（続報）一、日本建築学会大会 学術講演梗概集 P. 525 526、1989.10

8)下田吉之、花井裕、水野稔 : 地下鉄を例とした地下空間の熱㙏境シミュレー

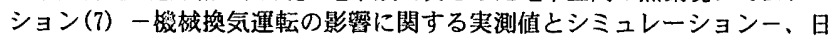
本建築学会大会学術詇演槙概集 PP. 1403 1404、1990.10

9) 花井裕、下田吉之、水野稳：地下鉄樥内の高温化対策に関する研究 ープラッ トホームスクリーンの熱的有効性一、日本建築学会大会学術鹪演梗概集 PP. $1401 \sim 1402 、 1990.10$

10)黑本英智、前川哲也、他 3 名: 地下鉄トンネルの排熱利用に関する研究 (そ の 1 : 実測) 、空気調和・衛生工学会学術譵演会講演諭文集 PP. $137 \sim 140$ 、 1990. 10

11) 高木婜二、太田勝也、他 3 名: 地下鉄トンネルの排熱利用に関する研究 (そ の2：予测手法及び排熱回收量）、空気調和・徨生工学会学術講演会講演諭 文集 PP. 141 144、1990.10

12) 高本㹂二、太田勝也、他 3 名: 地下鉄トンネルの排熱利用に関する研究 (そ

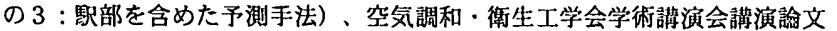

集 PP. 733 736、1991，10

13) 小野弘臣、岩井清、他 4 名: 地下鉄トンネルの排熱利用に関する研究 (そ

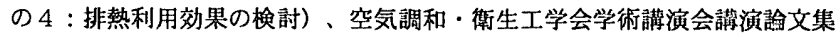
PP. 1185 1188、1992.10

14）下田吉之、水野稔：地下空間における地盤の吸熱勃果に関する研究 第 1 報一夏期の室温を制約条件とする限界発熱量の基本的特性一、空気調和・衛 生工学会諭文集 No. 43、PP. 49 58、1990.6

15）下田吉之、花井裕、水野稳：地下空間における地盉の吸熱效果に関する研 究 第 2 報一地下鉄構内の気温形成に及ぼす柕械換気と地盤吸放熱の影婹に 関する蚞的一、空気調和・衛生工学会詥文集 No.53、PP. 1 12、1993. 10 16) 吉田治典 : 地下鉄内の温度、熱負荷予測のためのシミュレーション、空気 調和・衛生工学会学術满演会請演論文集 PP. 317 320、1980.10

17）武田仁、矢㟨㴡史 : 地下鉄の排熱に関する基磁的調查 その 3 有限要素法によるトンネル内熱収支シミュレーション、日本建筑学会学術講 演梗酷集 PP. 479 480、1993. 9

18）武田仁、矢陭㴡史 : 地下鉄の排熱に関する調㚗研究（その 3) 一トンネル 部の温熱想境シミュレーションー、空気調和・衛生工学会学術講演会講演㻅 文集 PP. 337 340、1994. 10

19）吉田治典、伊丹清、寺井俊夫、他 3 名 : 地下鉄道における冬期熱回收と百 期温度予测、空気調和・衛生工学会諭文集、No. 61、PP. 13 23、1996. 4 20) 0. C. Zienkiemicz and R. L. Taylon: The Finite Elenent Method Forth Edition. McGrap-Hill Book Co. 1989

21）日本熱物性学会編：熱物性ハンドブックＰP. 488〜 489、蚨踶堂、1990

（1996年12月10日原稿受理，1997年 5 月 26 日採用決定） 